\title{
The Construction of Workers' Identity in Liminal Spaces
}

\author{
ROBERTA SFERRAZZO \\ sferrazzo.roberta@gmail.com \\ LUMSA University
}

\begin{abstract}
In the last decade, advances in technology have transformed the way in which we work, making it more and more fluid. One manifestation of this phenomenon is the fact that the border between work and non-work is disappearing. Many people, indeed, often work even on weekends. Moreover, a large number of workers continue working outside their home or their office environments. For example, it is more and more frequent to see managers or employees engaged in work calls in airports, public transport, cafés, hotels or other 'liminal spaces'. These spaces have become a part of workers' daily routines and contribute to building their identities in a changing world. In this article, I consider the concepts of liminality and of identity, as discussed in the literature. Then, I examine the construction of workers' identity in these 'places of passage'. I focus, especially, on what happens both in public transport and in other 'places of passage', such as cafés, airports and railway stations.
\end{abstract}

\section{Introduction}

The scholar Casey (1993), in his book Getting Back into Place: Toward a Renewed Understanding of the Place-World, connects spaces with people's ability to dwell within them. He describes how people create a sense of stability and belonging in the places they inhabit. Moreover, he argues that "the place we occupy, however briefly - has everything to do with what and who we are (and finally, that we are)" (Casey, 1993: xiii, emphasis in the original). Among these places, it is possible to make a distinction between those that are dominant and those that are liminal. The former are places that are stable, such as the home and the workplace; conversely, the latter include places of passage or transition, such as railway stations, airports, hotels, cafés, and so on.

Several scholars (Duffy, 1997; Donkin, 2009; Shortt, 2015) stress that nowadays many people do their business activities in transitory spaces. This is happening especially as work is becoming more and more fluid in nature (Donkin, 2009). Both dominant and transition spaces can strongly influence workers' or organisations' identity (Gagliardi, 1990; Yanow, 2006). In reference to the latter, for example, lifts are useful sites for communicating corporate goals, by hanging posters inside; hence, they could reveal something about the identity of the organisation (Dale and Burrell, 2008: 283). Moreover, according to Dale and Burrell (2008), in liminal spaces there is the opportunity for workers' emotions, identity and meaning to arise.

Unlike the two scholars just mentioned, Augé (1995) defined liminal spaces - such as airports, hotels, and motorways - as 'non-places'. In Augé's (1995: 77) view, liminal spaces - unlike 'places' - do not allow for the creation of identity. In response to Augé (1995), Shortt (2015) 
empirically demonstrates why liminal spaces cannot be defined as 'non-places', arguing: "think of graffiti on street corners or the 'usual spots' snatched up in public parks by groups of teenagers to notice how individuals, who may lack their own formal territories, often attempt to assert a sense of power, control and subjectivity and create their own footholds within the liminal spaces around them" (Shortt, 2015: 653).

In this article, I share Shortt's (2015) ideas related to liminal spaces, and in particular, I seek to understand the extent to which certain specific liminal spaces shape workers' identities. I will focus, especially, on public transport, such as buses, trains, undergrounds, and on places of passage, such as railway stations and airports.

To answer this question, I have structured the article as follows. After having specified the type of methodology used, I will offer an overview of the current literature on liminality and identity. Next, I will provide some brief comments oriented to illustrate how workers' identity can arise also in liminal spaces. Finally, I will propose my conclusions and ideas for future research.

\section{Methodology}

For the methodology used to identify relevant published output related to the concepts of both liminality and identity, I used the 'snowballing' technique (Greenhalgh and Peacock, 2005). I looked, in particular, for the words 'liminality' and 'identity' in papers published in business and management journals by using four electronic databases: Web of Science, PsycINFO, JSTOR and Google Scholar. Then, among the 200 articles found, I selected the main contributions that best fit with the conceptual analysis of this article. In fact, I quoted both the most cited authors dealing with liminality and identity in literature, and those scholars who applied them in relation to work and organisations.

\section{The spreading of liminality in literature}

In the organisational literature, several authors have focused in depth on the concept of rites of passage (Trice and Beyer, 1984; Schultz, 1991; Eriksson-Zetterquist, 2002; Islam and Zyphur, 2009; Mayrhofer and Iellatchitch, 2004). For example, Schultz (1991: 503) used the expression "rite of transitions" to indicate "the ritualization of the entry and the exit of each symbolic domain". Trice and Beyer identified rites of passage as rituals simplifying the transitions of "persons into social roles and statuses that are new for them" (Trice and Beyer, 1984: 657). Eriksson-Zetterquist (2002) evoked the concept of rites in the organisational context by describing a trainee program in a transnational company. Moreover, Matrhofer and Iellatchitch (2004) recognised the importance of rites of passage for creating a sense of job security.

The anthropologists Van Gennep (1960 [1909]) and Turner $(1974,1982)$ introduced the notion of liminal space to indicate a period of time/space 'in between', occurring especially during an individual's rite of passage (also called 'liminal rites' by Van Gennep). Van Gennep (1960 [1909]) defined this period of liminality as temporary, transitory, and related to uncertainty. He distinguished, in particular, among three levels of a rite of passage: separation, transition and incorporation. The first one - the separation - includes a departure from the previous life 
of individuals involved. The second phase - the transition - involves the condition of liminality, experienced by people who left their previous social environments. Finally, the incorporation phase consists in people entering in a new life.

Max Gluckman (1962) built upon Van Gennep's (1960 [1909]) research, focusing on the 'affiliation rites'. Victor Turner (1969) also developed Van Gennep's (1960 [1909]) work, sharing his vision of a non-well clarified identity or position for individuals entering in a liminal phase. He stressed, in particular, that (Turner, 1969: 95):

The attributes of liminality or a liminal personae ('threshold people') are necessarily ambiguous, since this condition and these persons elude or slip through the network of classifications that normally locate states and positions in cultural spaces. Liminal entities are neither here nor there; they are betwixt and between the positions assigned and arrayed by law, custom, convention and ceremonial.

More specifically, Turner (1991) identified the three phases mentioned above, although he referred to them with different terms. Turner (1991: 94-95), in particular, held these stages to be: (a) the separation from the "social structure"; (b) the entrance in the anti-structure (the "communitas"), and (c) the rehabilitation in the ordinary social context. Turner (1982: 27) saw the anti-structure phase as a liminal space, one that is free from "structural obligations". Furthermore, he substituted Van Gennep's (1960 [1909]) term 'liminality' with 'liminoid', to indicate something "not quite liminal" (Turner, 1982: 32).

However, I have here chosen to use the classic word 'liminality', considering that other scholars recognised that there is not a 'great divide' between the two words (Sahlins, 1993, 2000).

In the literature, the concept of liminality began to gain momentum two decades ago. Starting from the works of Van Gennep (1960 [1909]) and Turner (1969, 1982, 1991), scholars have applied the concept of liminality in a wide variety of academic fields, including education (Meyer and Land, 2005; Cook-Sather, 2006), health studies (Peleg et al., 1999; Pearce, 2003), tourism and leisure (Preston-Whyte, 2004; Pritchard and Morgan, 2006), social/cultural geography (Shields, 1991; Andrews and Roberts, 2012; Thomassen, 2012) and consumer research (Mehta and Belk, 1991).

Some authors (Turner, 1982; Ashforth, 2001: 14) have defined liminality as both as a psychological state implying the lack of a link between the self and an important social context, such as work, and as the possibility to be "betwixt and between" two conflicting identities (Newman, 1999: 91; Ibarra, 2003). Moreover, some academics discuss liminality in relation to job loss or retirement, characterised by a lack of identity (Newman, 1999; Ashfort, 2001).

The notion of liminality is gaining ground also in the area of organisation studies. Among others, Garsten (1999) applies the concept of liminality to study temporary employees. Tempest and Starkey (2004) connect it with individual and organisational learning, whereas Hawkins and Edwards (2013) associate it with leadership learning for management and business undergraduate students. Sturdy et al. (2006) use it to analyse business dinners. Ibarra (2007) links it to identity transitions, and Beech (2011) relates it to identity reconstruction. Moreover, Czarniawska and Mazza (2003), in their research, apply the condition of liminality to the activity of consulting. 
Thomassen (2012) highlights that the notion of liminality - as predominantly discussed in the literature - concerns a temporal dimension. This derives from Van Gennep's (1960 [1909]) consideration of liminal space as those periods of time in which individuals live ritualistic passages from one state to another. However, Van Gennep (1960 [1909]) also describes liminal spaces in a physical sense, such as when he analyses borders and doorways in rituals. In fact, even Thomassen (2012: 26) stresses that "the spatial dimensions of liminality can relate to specific places $[\ldots]$ a doorway $[\ldots]$ area or zones $[\ldots]$ border areas $[\ldots]$ prisons $[\ldots]$ airports".

In the literature, several authors have analysed this physical nature of liminal spaces. For example, Preston-Whyte (2004: 350) identified beaches as "limbo-like space(s) often beyond normal social and cultural constraints. In these spaces can be found brief moments of freedom and escape from the daily grind of social responsibilities". Pritchard and Morgan (2006: 764) define hotels as liminal spaces where "anonymity, romance and adventure" can arise. Iedema et al. (2012: 41) examine hospital corridors, showing how they are a liminal space in which persons can engage in conversations. Hence, liminal spaces can be seen both in a physical/spatial manner and in a temporal manner. Here, I focus on the former.

However, before explaining how the physical/spatial dimension of liminal spaces relates to workers' identity, it is necessary to examine the literature relating to the concept of identity.

\section{The concept of identity}

The field of identity theory is vast; indeed, it is discussed on multiple levels, including that of organisational, professional, individual and social studies. Leary and Tangney (2003) underline that the theme of identity has been examined for nearly 3000 years within religious philosophies, such as Buddhism. Current debates on identity are based on Enlightenment philosophers' ideas, considering for example the thought of Locke, Descartes, Hume, Kant, and so on. In the psychological field, questions on the self arose especially with Freud, who inspired the identities-oriented research cognitive psychology (McCall and Simmons, 1966; Stryker, 1980). Nowadays, in the area of sociology, scholars especially blend the theories of Marx (1972), Cooley (1902) and Mead (1934) to analyse the matters of the self and identity. These two elements sometimes appear as overlapping, and many authors do not distinguish between them. However, in Giddens' (1991: 53) words, self-identity is "the self as reflexively understood by the person [...] self-identity is continuity (across time and space) as interpreted reflexively by the agent". On the contrary, in Sveningsson and Alvesson's (2003: 1168) definition, identity is "the (conscious) struggle to respond to the question 'who am I'".

The notion of identity is connected to the different meaning that an individual or people attach to oneself and others (Gecas, 1982). These meanings refer to people's social roles (social identities) as well as to their character traits (personal identities) (Gecas, 1982; Ashfort, 2001). According to some authors (Stryker and Serpe, 1982; Ebaugh, 1988; Ashforth et al., 2001), people have many changing identities, but some are more embedded in their daily life, while others are significant only under specific circumstances. In Ebaugh's (1988) view, work identities have a high degree of intensity, which is the degree of effort used in the integration between the self and the role one must play. Moreover, according to Hughes (1958), people have several 'master statuses' around which they organise their self-identities and by which 
they are recognised in society. These master statuses concern sex, family and occupational roles.

Multiple identities constitute the self-concept and they are socially constructed and negotiated (Cooley, 1902; Mead, 1934; Goffman, 1959; Baumeister, 1986). These mutable identities coexist within a self that remains stable across situations and over time (Breakwell, 1986; Baumeister, 1998).

In organisation literature, various authors have studied both identity construction and identity work (Snow and Anderson, 1987; Kunda, 1992; Alvesson and Willmott, 2002; Fiol, 2002; Collinson, 2003; Costas and Fleming, 2009; Thornborrow and Brown, 2009; Whittle et al., 2009). Snow and Anderson (1987: 1348) define identity work as "the range of activities individuals engage in to create, present, and sustain personal identities that are congruent with and supportive of the self-concept". Moreover, according to Kunda (1992), the notion of identity work cannot be separated from the concept of role. In fact, he defines a role as a disposition related to how organisational members should feel about themselves and their work. In dealing with identity construction/identity work, Alvesson and Willmott (2002) investigated interactions such as managerial efforts to 'manufacture' subjectivities. Collinson (2003) explores employees' resistance (considered as a form of emancipation from the employer), which allows them to construct a more positive sense of self to that provided by the organisation. Thornborrow and Brown (2009) examine people trying to switch from a 'current self' to an aspirational identity. Conversely, Costas and Fleming (2009) discuss people seeking to leave their work-imposed identity to enter into their 'authentic' self. In Fiol's (2002) view, it is possible to recognise identities as characterised by a 'before' and an 'after'. Moreover, according to Whittle et al., (2009), multiple identities can co-exist in the same person.

Other scholars define identity work also as people's involvement referred to forming, maintaining or strengthening their identities (Snow and Anderson, 1987; Svenigsson and Alvesson, 2003), including the effort "by self (in claiming) and 'other' (in granting)" (Bartel and Dutton, 2001: 120) that builds and supports those identities. Through this line of thinking it is possible to understand how people both cope with multiple or ambiguous identities (Elsbach, 1999; Ashforth et al., 2000; Pratt and Foreman, 2000; Bartel and Dutton, 2001; Svenginsson and Alvesson, 2003) and shape role identities to better adapt their sense of self (Van Maanen, 1998; Ibarra, 1999; Kreiner et al., 2006; Pratt, Rockmann and Kaufmann, 2006).

Job crafting academics emphasised some individuals' reactions oriented to change the task, relational and cognitive dimensions of their work (Wrzesniewski and Dutton, 2001; Berg, Dutton and Wrzesniewski, 2013; Lazazzara, Tims and de Gennaro, 2020). In this way, workers can experience a higher level of job autonomy, with connected implications for their skills, talents, and identities (Cable, 2019).

All things considered, how could the notion of identity be linked with the phenomenon of work in a changing world? To answer this question, in the following section, first, I will describe the nature of contemporary work, then I will explore its link with the construction of workers' identity. 


\section{The arising of workers' identity in liminal spaces}

In the literature, there is a broad debate related to the nature of contemporary work. For example, Putnam (2000) argues that work is contributing to the decline of our society, as it totally dominates our lives. Moreover, Hochschild (2001) stresses that work is substituting home and social ties. The scholar Garsten (1999) highlights the "flexible" nature of contemporary work, arguing that "[ $t$ ] he 'flexibility discourse' is ripe with positive images of versatile organizations employing likewise versatile employees, challenging the traditional institutions of stable, enduring organizations and workforces" (Garsten, 1999: 601). Moreover, Garsten (1999) recognises the 'betwixt and between' nature of contemporary work contracts, which are continuously changing between a temporary and a fixed dimension. Due to its fluid and flexible nature, the organisation has also been defined as a 'gas' that spreads into every part of life (Deleuze, 1992).

Bauman (1995: 268-269) describes the fluid spatial dimension of workers well, claiming that:

The life of men and women of our time is much like that of tourists-through-time: they cannot and would not decide in advance what places they will visit and what the sequence of stations will be; what they know for sure is that they will keep on the move, never sure whether the place they have reached is their final destination. Whoever knows that is unlikely to strike deep roots in any of the places and to develop too strong an attachment to the locals. What s/he is likely to do is to treat each place as a temporary stay, significant only through the satisfactions $\mathrm{s} / \mathrm{he}$ derives from it; but $\mathrm{s} / \mathrm{he}$ must be ready to move again, whenever satisfaction diminishes or whenever greener pastures beckon elsewhere.

The spaces where people work change constantly, and this unavoidably generates a strong temporal-spatial instability. In fact, as highlighted by Tempest et al. (2007: 1050):

[...] to make companies more responsive to dynamic, global markets flexible organizational forms are being advocated that build on network forms via project teams, virtual organizations, and other transient forms of organization that are lean in number and focused on demanding goals.

According to Garsten (1999: 606), "liminality in the context of work may be seen as an alternative to work as organized and structured in bureaucratic, industrial organizations; an alternative to regular, full-time employment contracts". I would add that liminality - in the context of work - may also be found in the continuous movement between the places where people do their jobs. In fact, in the course of doing their jobs, people continuously experience rites of passages from one place to another. Despite its discontinuous nature, the workplace still constitutes the main place for the formation of self-identity (Turner, 1971; Miller and Rose, 1995). I stress, in particular, that workers' identity can be shaped by different and fluid places in which people work every day. To explain this, it is helpful to examine the connection between liminal spaces and the construction of workers' identity.

I define people working in liminal places as 'liminal workers' who continuously live at the boundaries between entering and leaving. However, liminal places also contribute to the building of workers' identity. In fact, as highlighted by Turner (1982), liminal places allow 
people to acquire new skills by exiting from institutional norms and to transfer them into the mainstream (Schein, 1996; Schrage, 1999; Brown and Starkey, 2000).

The concept of identity derives from the Latin word ' $i d$ ', which means 'the same'. Apparently, this etymological origin seems as opposed to that of the word liminality, deriving from the Latin word 'limen' (meaning threshold). This latter, indeed, indicates a period of time/space at the boundary. There appears to be a paradox here: the stable nature of identity seems incompatible with the uncertain and transitory nature of liminal spaces.

Despite this ambiguity, I enlarge the connection between liminality and identity by considering both public transport places and other places of passage as spaces fostering workers' identity constructions.

Blending Turner's (1974: 13) words, in liminal spaces "anything may happen" and people can experience a degree of freedom. In fact, in traditional workplaces, employees can feel judged and observed by both their clients and their colleagues. Conversely, when they work in liminal spaces, they are not controlled by other people, for instance for their clothing. The act of answering a work call in a train or to sending a work email in the airport - for example - identify people as 'workers' within the liminal space in which they are situated. Hence, working in liminal spaces fosters a sort of social identification, as it allows people to express who they are outside their office environments. Moreover, many people freely choose to work in liminal spaces, for example, in a particular bar where they feel comfortable. This choice could become a routinise event of their working life.

In my view, in liminal places, workers can show themselves to unknown people (representing the society as a whole) as strongly engaged in their work activities. This may contribute to reinforcing their social identity. Furthermore, working in a bar or in other place of passage, such as airports or railway stations, allows workers to isolate themselves; this episode is typical of rites of passage, which imply an 'emptying' of people entering in the rite. The resulting factor of 'isolation' allows workers to concentrate, so as to both reinforce their identity and maybe also to increase their work performance.

In this way, workers jump out of the world to build their sense-making, understanding that the sense of the world is outside the world (Wittgenstein, 1994). This may happen as liminal rites generate a sort of detachment from the world. Furthermore, thanks to the nature of these rites, even the conditions for overcoming this same detachment are created.

Week-ends, by interrupting the flow of daily time, have also been defined as liminal spaces, as people exit from their working activities to enter into a dimension of rest (Islam, 2016). Similarly, when workers enter places of passage, in a sense, they feel freer to the same extent as when they enter into the week-end. Of course, this could be true for those workers who are not so overwhelmed with work or anxious about making ends meet that continuing to work in public places is a free choice for them. In fact, in places of passages, they can decide or to rest (for example, sleeping or reading a book) either to continue working, and this happens also during the week-end.

Their free choice allows us to understand how liminal spaces can determine worker's identity. In fact, although in most cases, liminal spaces could include an element of rest (in case of both the week-end and some places of passage), nevertheless, people crossing into them can freely decide to continue their working activities. The choice of rest rather than continuing to work contributes to delineating worker's identity. 


\section{Conclusions and future research prospects}

The organisation of work is constantly changing as technology evolves, allowing people to work everywhere. Most workers are affected by this process of change, which implies transformations in the construction of workers' identities.

With reference to these continuous changes in contemporary work, Garsten (1999: 604) writes about "temporary workers", highlighting that "the mobile and transient position of temps [...] undermines the development of community in the workplace; which becomes inherently fragile and episodic". In fact, it is becoming more and more difficult to foster the creation of bonds in interpersonal relationships within organisations due to the fluid structure of companies.

The construction of workers' identity can verify also in places of passage and public transport, which are liminal spaces where 'liminal workers' can continue doing their jobs, even outside their workplaces. In a sense, every place in which we live could nowadays become a 'workplace', from our home to other social environments. This is happening because of the extremely flexible nature of work and of organisations.

Given this picture, future research could aim, for example, to study the effects on workers' identities of the space-time instability of their jobs. In future research, academics could investigate how specific work conditions, the kind of activity, the duration of work in liminal spaces and even the experience one has about working in liminal spaces could be relevant to the identity (or multiple identities) development process. Furthermore, a long tradition in the managerial and organisational studies suggests that the characteristics of the work situation is crucial in influencing behaviours, motivations, goals, attitudes and emotions of the individuals. In order to discover if this is also true for liminal spaces, future research could investigate how specific characteristics (comfort, available technologies, etc.) of liminal spaces contribute to shape the workers' identities in different ways. Finally, another future path of research could examine how this instability affects workers' performance and work-life balance.

\section{Keywords}

identity; identity work; liminality; liminal spaces; places of passage

\section{Reference list}

Alvesson, M., and Willmott, H. (2002), "Identity Regulation as Organizational Control", Journal of Management Studies, 39 (5): 619-644.

Andrews, H., and Roberts, L. (2012), Liminal Landscapes: Travel, Experience and Spaces InBetween, London: Routledge.

Ashforth, B.E. (2001), Role Transitions in Organizational Life: An Identity-based Perspective, Lawrence Erlbaum Associates, Publishers. 
Ashforth, B.E., Johnson, S.A., Hogg, M., and Terry, D. (2001), "Which Hat to Wear", Social Identity Processes in Organizational Contexts: $32-48$.

Ashforth, B.E., Kreiner, G.E., and Fugate, M. (2000), “All in a Day's Work: Boundaries and Micro Role Transitions", Academy of Management Review, 25 (3): 472-491.

Augé, M. (1995), Non-Places: Introduction to an Anthropology of Supermodernity, London: Verso.

Bartel, C.A., and Dutton, J.E. (2001), “Ambiguous Organizational Memberships: Constructing Organizational Identities in Interactions with Others", in M.A. Hogg and D.J. Terry (eds), Social Identity Processes in Organizational Contexts, pp. 115-130, Philadelphia (PA): Psychology Press.

Bauman, Z. (1995), Life in Fragments: Essays in Post-modernity Morality, Oxford: Blackwell.

Baumeister, R.F. (1986), Identity: Cultural Change and the Struggle for Self, New York (NY): Oxford University Press.

Baumeister, R.F. (1998), "The Self", in D.T. Gilbert, S.T. Fiske and G. Lindzey (eds), The Handbook of Social Psychology (4th edn.), pp. 680-740, Boston (MA): McGraw-Hill.

Beech, N. (2011), "Liminality and the Practices of Identity Reconstruction", Human Relations, 64 (2): 285-302.

Berg, J.M., Dutton, J.E., and Wrzesniewski, A. (2013), "Job Crafting and Meaningful Work", in B.J. Dik, Z.S. Byrne and M.F. Steger (eds), Purpose and Meaning in the Workplace, pp. 81104, Washington (DC): American Psychological Association.

Breakwell, G.M. (1986), Coping with Threatened Identities, London: Methuen.

Brown, A.D., and Starkey, K. (2000), “Organizational Identity and Learning: A Psychodynamic Perspective", Academy of Management Review, 25 (1): 102-121.

Cable, D.M. (2019), Alive at Work: The Neuroscience of Helping Your People Love What They Do, Cambridge (MA): Harvard Business Press.

Casey, E.S. (1993), Getting Back into Place: Toward a Renewed Understanding of the Place-World, Bloomington (IN): Indiana University Press.

Collinson, D.L. (2003), “Identities and Insecurities”, Organization, 10 (3): 527-547.

Cook-Sather, A. (2006), "Newly Betwixt and Between: Revising Liminality in the Context of a Teacher Preparation Program", Anthropology and Education Quarterly, 37 (2): 110-127.

Cooley, C.H. (1902), Human Nature and the Social Order, New York (NY): Scribner's.

Costas, J., and Fleming, P. (2009), “Beyond Dis-Identification”, Human Relations, 63 (3): 353378.

Czarniawska, B., and Mazza, C. (2003), "Consulting as a Liminal Space”, Human Relations, 56 (3): 267-290.

Dale, K., and Burrell, G. (2008), The Spaces of Organization and the Organization of Space: Power, Identity and Materiality at Work, London: Palgrave.

Deleuze, G. (1992), “Postscript on the Societies of Control”, October, 59: 3-7.

Donkin, R. (2009), The Future of Work, New York (NY): Palgrave Macmillan.

Duffy, F. (1997), The New Office, London: Conrad Octopus. 
Ebaugh, H.R.F. (1988), Becoming an Ex: The Process of Role Exit, Chicago (IL): University of Chicago Press.

Elsbach, K.D. (1999), “An Expanded Model of Organizational Identification”, in B.M. Staw and R.I. Sutton (eds), Research in Organizational Behavior, pp. 163-200, Greenwich, CT: JAI.

Eriksson-Zetterquist, U. (2002), "Gender Construction in Corporations", in B. Czarniawska and H. Höpfl (eds), Casting the Other: Production and Maintenance of Inequality in Organizations, pp. 89-103, London: Routledge.

Fiol, C.M. (2002), "Capitalizing on Paradox: The Role of Language in Transforming Organizational Identities", Organization Science, 13 (6): 653-666.

Gagliardi, P. (1990), Symbols and Artifacts: Views of the Corporate Landscape, New York (NY): Walter de Gruyter.

Garsten, C. (1999), "Betwixt and Between: Temporary Employees as Liminal Subjects in Flexible Organizations", Organization Studies, 20 (4): 601-617.

Gecas, V. (1982), “The Self-Concept”, Annual Review of Sociology, 8: 1-33.

Giddens, A. (1991), Modernity and Self-Identity, Cambridge: Polity Press.

Gluckman, M. (1962), Essays on the Ritual of Social Relations, Manchester: Manchester University Press.

Goffman, E. (1959), The Presentation of Self in Everyday Life, New York (NY): Anchor Books.

Greenhalgh, T., and Peacock, R. (2005), "Effectiveness and Efficiency of Search Methods in Systematic Reviews of Complex Evidence: Audit of Primary Sources", British Medical Journal, 331: 1064-1065.

Hawkins, B., and Edwards, G. (2015), "Managing the Monsters of Doubt: Liminality, Threshold Concepts and Leadership Learning", Management Learning, 46 (1): 24-43.

Hochschild, A. (2001), The Time Bind: When Work Becomes Home and Home Becomes Work, New York (NY): Owl Books.

Hughes, E.C. (1958), Men and Their Work, Glencoe (IL): Free Press.

Ibarra, H. (1999), "Provisional Selves: Experimenting with Image and Identity in Professional Adaptation", Administrative Science Quarterly, 44 (4): 764-791.

Ibarra, H. (2007), "Identity Transitions: Possible Selves, Liminality and the Dynamics of Voluntary Career Change", INSEAD Faculty and Research Working Paper: 1-57.

Ibarra, H. (2003), Working Identity: Unconventional Strategies for Reinventing Your Career. Boston (MA): Harvard Business School Press.

Iedema, R., Long, D., and Carroll, K. (2012), “Corridor Communication, Spatial Design and Patient Safety: Enacting and Managing Complexities", in A. van Marrewijk and D. Yanow (eds), Organizational Spaces: Rematerializing the Workaday World, pp. 41-57, Cheltenham: Edward Elgar.

Islam, G. (2016), “Weekend as Community, Consumption and Colonization: Struggles over Liminal Time in Two Days, One Night", M@n@gement, 19 (2): 146-151.

Islam, G., and Zyphur, M. (2009), "Rituals in Organizations: A Review and Expansion of Current Theory", Group \& Organization Management, 34 (1): 114-139. 
Kreiner, G.E., Hollensbe, E.C., and Sheep, M.L. (2006), “Where Is the 'Me' among the 'We'? Identity Work and the Search for Optimal Balance", The Academy of Management Journal, 59 (5): 1031-1057.

Kunda, G. (1992), Engineering Culture, Philadelphia (PA): Temple University Press.

Lazazzara, A., Tims, M., and de Gennaro, D. (2020), “The Process of Reinventing a Job: A MetaSynthesis of Qualitative Job Crafting Research", Journal of Vocational Behavior, 116: 1-18.

Leary, M.R., and Tangney, J.P. (2003), "The Self as an Organizing Construct in the Behavioral and Social Sciences", in M.R. Leary and J.P. Tangney (eds), Handbook of Self and Identity, pp. 3-14, New York (NY): Guilford Press.

Marx, K. (1972), The Marx-Engels Reader (Vol. 4), New York (NY): Norton.

Mayrhofer, W., and Iellatchitch, A. (2004), "Rites, Right? the Value of Rites De Passage for Dealing with Today's Career Transitions", Career Development International, 10 (1): 52-66.

McCall, G.J., and Simmons, J.L. (1966), Identities and Interactions: An Examination of Human Association in Everyday Life, New York (NY): Free Press.

Mead, G.H. (1934), Mind, Self, and Society, Chicago (IL): University of Chicago Press.

Mehta, R., and Belk, R.W. (1991), “Artifacts, Identity, and Transition: Favourite Possessions of Indians and Indian Immigrants to the United States", Journal of Consumer Research, 17 (4): 398-411.

Meyer, J.H.F., and Land, R. (2005), “Threshold Concepts and Troublesome Knowledge 2: Epistemological Considerations and a Conceptual Framework for Teaching and Learning", Higher Education, 49 (3): 373-388.

Miller, P., and Rose, N. (1995), "Production, Identity, and Democracy", Theory and Society, 24: 427-467.

Newman, K.S. (1999), Falling from Grace, Berkeley: University of California Press.

Pearce, C. (2003), “Corridor Teaching: Have You Got a Minute...?”, Australian Family Physician, 32 (9): 745-747.

Peleg, A., Peleg, R., Porath, A., and Horowitz, Y. (1999), "Hallway Medicine: Prevalence, Characteristics and Attitudes of Hospital Physicians", The Israel Medical Association Journal, 1 (4): 241-244.

Pratt, M.G., and Foreman, P.O. (2000), “Classifying Managerial Responses to Multiple Organizational Identities", Academy of Management Review, 25 (1): 18-42.

Pratt, M.G., Rockmann, K.W., and Kaufmann, J.B. (2006), “Constructing Professional Identity: The Role of Work and Identity Learning Cycles in the Customization of Identity among Medical Residents", Academy of Management Journal, 49 (2): 235-262.

Preston-Whyte, R. (2004), "The Beach as a Liminal Space”, in A.A. Lew, C.M. Hall and A.M. Williams (eds), A Companion to Tourism, pp. 349-359, Malden (MA): Blackwell Publishing.

Pritchard, A., and Morgan, N. (2006), "Hotel Babylon? Exploring Hotels as Liminal Sites of Transition and Transgression", Tourism Management, 27 (5): 762-772.

Putnam, R. (2000), Bowling Alone: The Collapse and Revival of American Community, New York (NY): Simon and Schuster. 
Sahlins, M. (1993), “Goodbye to Tristes Tropes: Ethnography in the Context of Modern World History", The Journal of Modern History, 65 (1): 1-25.

Sahlins, M. (2000), “Ethnographic Experience and Sentimental Pessimism: Why Culture Is Not a Disappearing Object", in L. Daston (ed.), Biographies of Scientific Objects, pp. 158-293, Chicago (IL): University of Chicago Press.

Schein, E.H. (1996), "Kurt Lewin's Change Theory in the Field and in the Classroom: Notes Toward a Model of Management Learning", Systems Practice, 9 (1): 27-47.

Schrage, M. (1999), Serious Play: How the World's Best Companies Simulate to Innovate. Boston (MA): Harvard Business School Press.

Schultz, M. (1991), "Transitions Between Symbolic Domains in Organizations", Organization Studies, 12 (4): 489-506.

Shields, R. (1991), Places on the Margins: Alternative Geographies of Modernity, London: SAGE.

Shortt, H. (2015), “Liminality, Space and the Importance of 'Transitory Dwelling Places' at Work", Human Relations, 68 (4): 633-658.

Snow, D.A., and Anderson, L. (1987), "Identity Work among the Homeless: The Verbal Construction and Avowal of Personal Identities", American Journal of Sociology, 92: 13361371.

Stryker, S. (1980), Symbolic Interactionism: A Social Structural Version, Menlo Park (CA): Benjamin/Cummings.

Stryker, S., and Serpe, R.T. (1982), “Commitment, Identity Salience and Role Behavior: Theory and Research Example", in W. Ickes and E.S. Knowles (eds), Personality, Roles, and Social Behavior, pp. 192-218, New York (NY): Springer-Verlag.

Sturdy, A., Schwarz, M., and Spicer, A. (2006), “Guess Who's Coming to Dinner? Structures and Uses of Liminality in Strategic Management Consultancy", Human Relations, 59 (7): 929-960.

Sveningsson, S., and Alvesson, M. (2003), “Managing Managerial Identities: Organizational Fragmentation, Discourse and Identity Struggle", Human Relations, 56 (10): 1163-1193.

Tempest, S., and Starkey, K. (2004), "The Effects of Liminality on Individual and Organizational Learning", Organization Studies, 25 (4): 507-527.

Tempest, S., Starkey, K., and Ennew, C. (2007), “In the Death Zone: A Study of Limits in the 1996 Mount Everest Disaster", Human Relations, 60 (7): 1039-1064.

Thomassen, B. (2012), "Revisiting Liminality: The Danger of Empty Spaces", In H. Andrews and L. Roberts (eds), Liminal Landscapes: Travel, Experience and Spaces In-Between, pp. 2135, London: Routledge.

Thornborrow, T., and Brown, A. (2009), “Being Regimented: Aspiration, Discipline and Identity Work in the British Parachute Regiment", Organization Studies, 30 (4): 355-376.

Trice, H.M., and Beyer, J. (1984), "Studying Organizational Cultures through Rituals and Ceremonials", Academy of Management Review, 9 (4): 653-669.

Turner, B.A. (1971), Exploring the Industrial Subculture, London: Macmillan.

Turner, V. (1969), The Ritual Process: Structure and Anti-Structure, London: Routledge \& Kegan Paul. 
Turner, V. (1974), Dramas, Fields and Metaphors, Ithaca (NY): Cornell University Press.

Turner, V. (1977 [1969]), The ritual process: Structure and anti-structure, London: Routledge \& Kegan Paul.

Turner, V. (1982), From Ritual to Theatre: The Human Seriousness of Play, New York (NY): Performing Arts Journal Publications.

Turner, V. (1991), The Ritual Process: Structure and Anti-Structure (7th edn.), Ithaca (NY): Cornell University Press.

Van Gennep, A. (1960 [1909]), The Rites of Passage, Chicago (IL): University of Chicago Press.

Van Maanen, J. (1998), "Identity Work: Notes on the Personal Identity of Police Officers", Paper presented at the Annual Meeting of the Academy of Management, San Diego (CA), USA, August 9-12.

Whittle, A., Meuller, F., and Mangan, A. (2009), "Storytelling and Character: Victims, Villains and Heroes in a Case of Technological Change", Organization, 16 (3): 425-442.

Wittgenstein, L. (1994), Tractatus Logico-Philosophicus (English Translation). London \& New York: Routledge.

Wrzesniewski, A., and Dutton, J.E. (2001), "Crafting a Job: Revisioning Employees as Active Crafters of Their Work", The Academy of Management Review, 26 (2): 179-201.

Yanow, D. (2006), "How Built Spaces Mean: A Semiotics of Space", in D. Yanow and P. Schwartz-Shea (eds), Interpretation and Methods: Empirical Research Methods and the Interpretive Turn, pp. 349-366, New York (NY): M. E. Sharpe. 